\title{
DOE Hydropower Program Annual Report for FY 2000
}

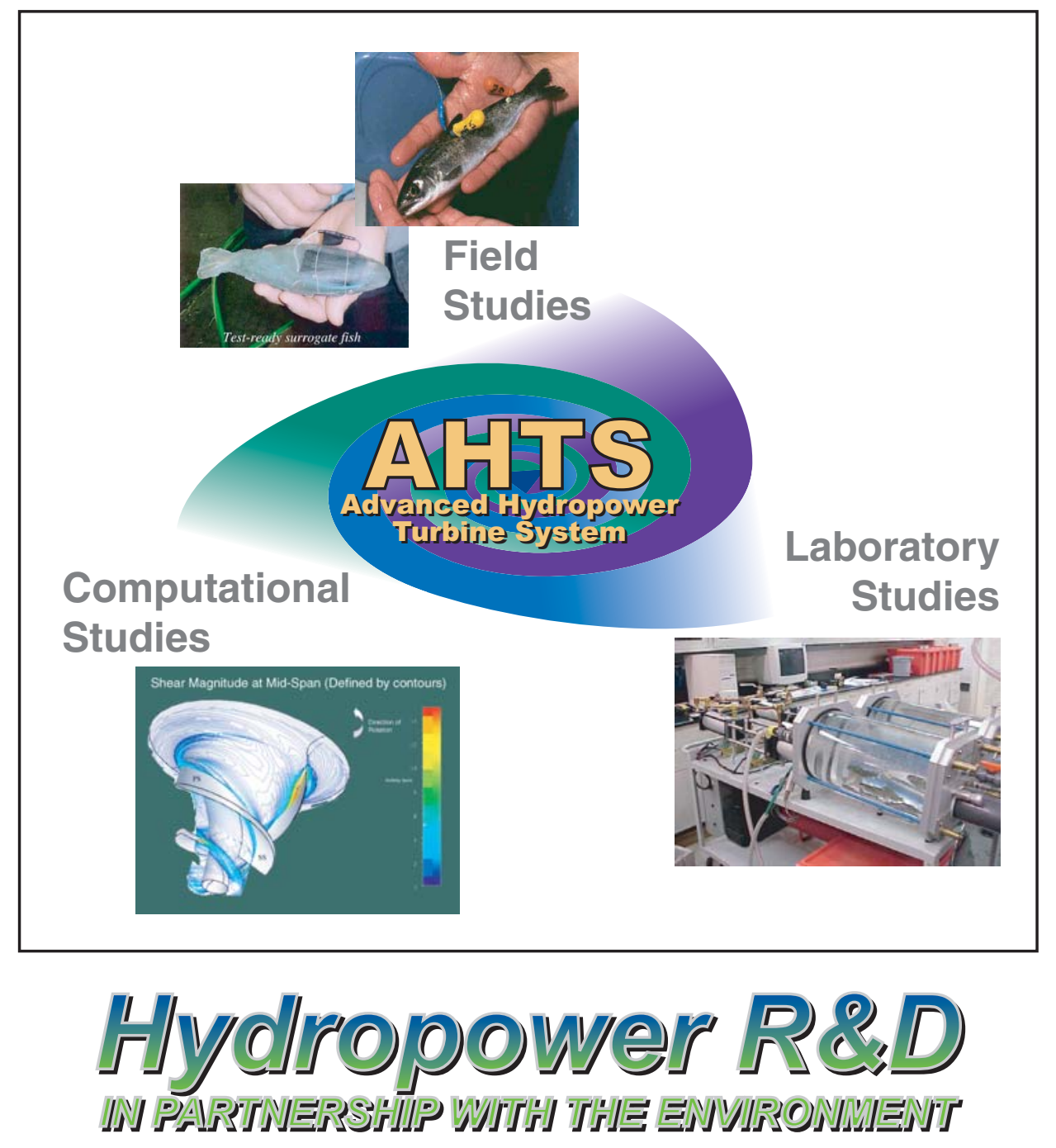

United States

Department of Energy 



\title{
DOE Hydropower Program Annual Report for FY 2000
}

\author{
M. J. Sale ${ }^{1}$ \\ G. F. Čada ${ }^{1}$ \\ D. D. Dauble ${ }^{2}$ \\ B. N. Rinehart ${ }^{3}$ \\ G. L. Sommers ${ }^{4}$ \\ J. V. Flynn ${ }^{5}$ \\ P. A. Brookshier ${ }^{6}$
}

April 17, 2001

\section{Prepared for the \\ U.S. Department of Energy Idaho Operations Office}

\footnotetext{
${ }^{1}$ Oak Ridge National Laboratory

2 Pacific Northwest National Laboratory

${ }^{3}$ Consultant

${ }^{4}$ Idaho National Engineering and Environmental Laboratory

${ }^{5}$ U.S. Department of Energy - Office of Biopower and Hydropower Technologies

${ }^{6}$ U.S. Department of Energy - Idaho Operations Office
} 



\section{CONTENTS}

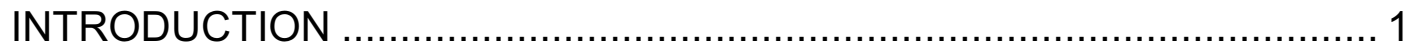

ADVANCED TURBINE DEVELOPMENT …......................................... 4

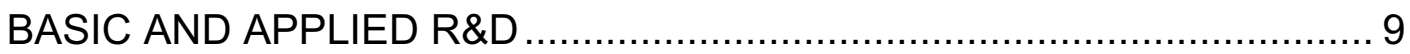

ENVIRONMENTAL MITIGATION AND OTHER STUDIES ...................... 16

LOW HEAD/LOW POWER HYDROPOWER TECHNOLOGY .................. 18

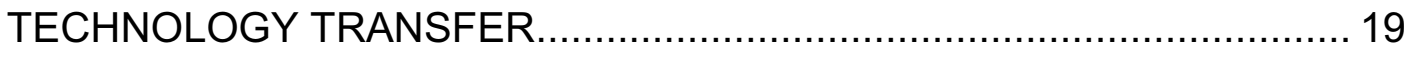

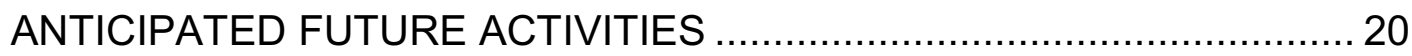

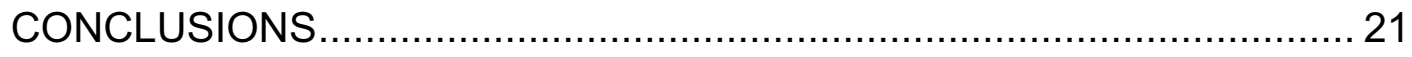

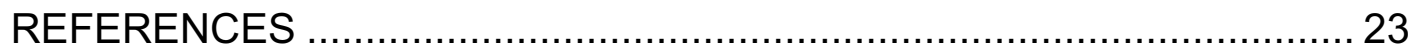




\section{DOE Hydropower Program Annual Report for FY 2000}

\section{INTRODUCTION}

This report describes the activities of the U.S. Department of Energy (DOE) Hydropower Program during Fiscal Year 2000 (October 1, 1999, to September 30, 2000). The Hydropower Program is organized under the DOE Office of Energy Efficiency and Renewable Energy, Office of Power Technologies, and Office of Biopower and Hydropower. Background, current activities, and future plans are presented in the following sections for all components of the Program.

\section{Technology Description}

Hydropower is one of the nation's most important renewable energy resources. According to the Energy Information Administration (EIA), hydropower currently provides about $9 \%$ of the nation's electricity, with an installed capacity of approximately $78,000 \mathrm{MW}$ (EIA 2001). Techniques for producing hydroelectricity from falling water have existed for more than a century. This technology has tremendous advantages over other energy sources: it is a reliable, domestic, renewable resource with large undeveloped potential, and it emits essentially none of the atmospheric emissions that are of growing concern, such as greenhouse gases. Hydropower projects can provide substantial nonpower benefits as well, including water supply, flood control, and recreation.

Hydropower also poses unique challenges in energy development, because it combines great benefits with some difficult environmental challenges. The benefits of hydropower can sometimes be offset by adverse environmental impacts (e.g., Mattice, 1991). The most frequent environmental issues faced by hydropower are fish injury and mortality from passage through turbines, as well as detrimental changes in the quality and quantity of downstream water.

Hydropower's share of generation is projected to decline through 2020 to about $6 \%$, due to a combination of environmental problems, regulatory complexity and pressures, and changes in energy economics. Almost no new hydropower capacity is predicted through 2020 (EIA 2001).

\section{Program Mission and Goals}

The mission of the DOE's Hydropower Program is to conduct research and development (R\&D) to improve the technical, societal, and environmental benefits of hydropower. The Program seeks to develop advanced hydropower technologies that 
will improve hydropower's environmental performance, and thereby allow it to co-exist with other water resource uses and remain a significant contributor to the nation's energy portfolio. Program activities include these five areas (Figure 1):

- Development of advanced hydropower turbines with enhanced environmental performance

- Basic and applied research that supports and enables new technology development

- Studies of environmental mitigation and other issues that affect hydropower development

- Development of unconventional technologies, such as low-head/lowpower generating equipment that can be implemented for distributed energy production

- Technology transfer.

Program activities focus on applied R\&D, managed by Federal personnel and performed by national laboratories and industry partners. Whenever possible, costsharing and other types of cooperation are used to leverage DOE funding. The Program uses a multi-faceted approach, combining engineering design and construction, field, laboratory, and computational studies.

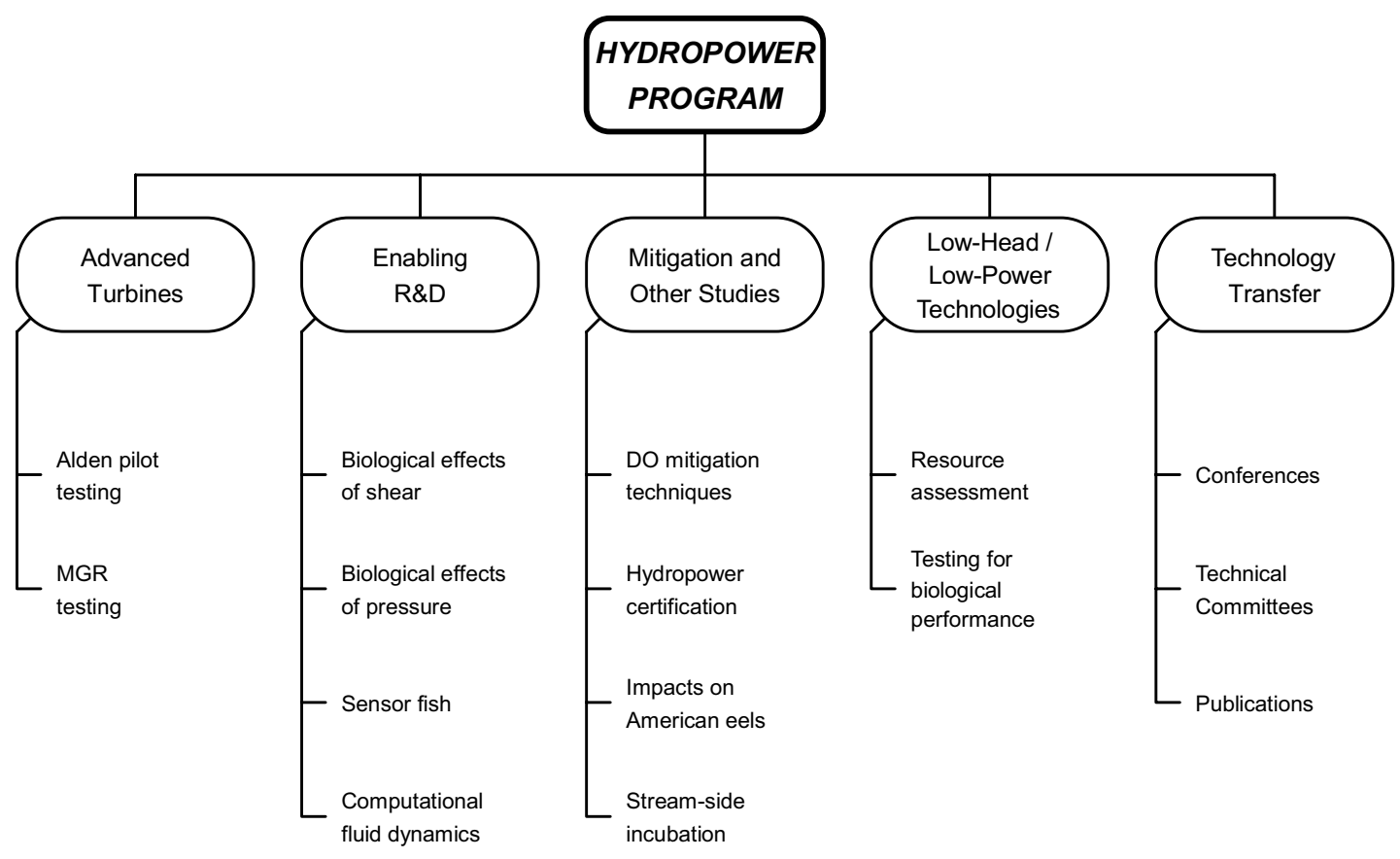

Figure 1. Current Activities of the DOE Hydropower Program. 


\section{Program Organization and Management}

Overall Hydropower Program guidance and direction are provided by the DOE Office of Biopower and Hydropower Technologies, and the program is managed by DOE's Idaho Operations Office in Idaho Falls, Idaho, with technical support from the Idaho National Engineering and Environmental Laboratory (INEEL), Oak Ridge National Laboratory (ORNL), and Pacific Northwest National Laboratory (PNNL). The lead laboratory for engineering and program management support is INEEL, and ORNL is the lead laboratory for environmental and computational support. The Program coordinates with the hydropower industry, including both private and public entities involved with hydropower development. An open peer-review process with industry and environmental resource agencies ensures that stakeholders are involved and that highpriority projects are being addressed.

A key approach for any hydro-related R\&D is the coordination among Federal entities and industry. The Program's Technical Committee reviews progress, evaluates results, and ensures coordination with related R\&D activities of other entities. This technical team consists of experts from the hydropower industry and state and Federal agencies. In addition, the reviews of specialists who are not members of the Technical Committee are obtained when appropriate. This active coordination provides "situational awareness," avoids duplication of research efforts, and creates a synergy among related research.

A combination of industry, universities, and federal facilities conduct program research activities. Where federal facilities have the equipment and personnel to reduce the overall cost to DOE, they are used for conducting R\&D. INEEL and ORNL are involved on the basis of their 20 years of hydropower-related biological, environmental, and engineering experience to help DOE and industry conduct R\&D activities. The Pacific Northwest National Laboratory (PNNL) is being used for the biological studies, taking advantage of their experience and facilities for conducting tests on fish.

\section{Background on Program Activities}

DOE has been supporting hydropower R\&D for more than 20 years. Important products in the early 1990s were two Environmental Mitigation Study reports. These studies provided greater understanding of environmental issues, and the benefits and costs of potential solutions. The first report (Sale et al. 1991) considered mitigation for problems associated with fish passage, dissolved oxygen, and instream flows. The second report (Frankfort et al. 1994) provided a detailed examination of the benefits and costs of upstream and downstream fish passage measures at 16 hydroelectric projects. Since then, a major emphasis of the Program has been the development of advanced, environmentally friendly turbines (see next section). In addition, the Hydropower Program has performed hydropower resource assessments, engaged in 
cost-shared research with industry, and promoted technology transfer. For example, DOE established a multi-agency team to quantify potential, undeveloped hydropower resources in the U.S. A preliminary resource assessment was completed in 1990, and the analyses have been refined and updated since then (Conner et al. 1998). The Program's contributions have been summarized in regular biennial reports (e.g., Rinehart et al. 1995) and on the DOE Hydropower Web site:

http://hydropower.id.doe.gov/).

The following sections describe activities of the DOE Hydropower Program during FY 2000.

\section{ADVANCED TURBINE DEVELOPMENT}

The goal of DOE's advanced turbine work is to improve the overall performance and acceptability of hydropower projects by developing and demonstrating advanced technology that reduces or eliminates adverse environmental effects. The highest priority environmental problems associated with turbines are: 1) injury and mortality to fish as they pass through turbines, 2) low dissolved oxygen downstream of the dams, and 3 ) altered stream flows and associated habitat for aquatic organisms (Sale et al. 1991; HCl 1992). The hydropower "system" that the current DOE program is concentrating on is defined by that area between the forebay of turbine inflows and the exit of the turbine's draft tube (Brookshier et al. 1995). These system boundaries may be expanded in future years, as resources allow.

DOE's Advanced Hydropower Turbine Systems (AHTS) program began in February 1993, when DOE, EPRI, and the Research and Development Committee of the National Hydropower Association (NHA) met to discuss new research initiatives (Sale et al. 2000). Shortly thereafter, NHA formed a non-profit organization called the Hydropower Research Foundation, Inc. (HRF) to support this kind of research. Later in 1993, NHA and HRF assembled financial contributions from nine utility members and from EPRI into $\$ 500,000$ to support joint research on advanced turbines. DOE agreed to match these industry contributions, producing a $\$ 1$ million fund to support the first phase of advanced turbine development. With this funding, competitive awards were made to Alden Research Laboratory, Inc./Northern Research and Engineering Corporation (ARL/NREC) and Voith Hydro, Inc. (Voith) in October 1995. Conceptual design reports were completed by both ARL/NREC (Cook et al. 1997) and Voith (Franke et al. 1997), and summarized by Odeh (1999).

In FY 2000, two projects were supported in the area of advanced turbine development: 1) pilot-scale testing of the new ARL/NREC turbine runner design, and 2) field tests of Voith's advanced designs of more conventional Kaplan turbines at Bonneville Dam on the Columbia River. 


\section{Pilot-Scale Testing of ARL/NREC Turbine Runner}

In the initial phase of the AHTS research, the ARL/NREC team developed a conceptual design for a new turbine runner that minimizes both the sources of injury to fish and the penalty on turbine efficiency (Cook et al. 1997; Hecker et al. 1997). The new runner, based on the shape of a pump impeller (Figure 2), minimizes the number of blade leading edges, reduces the pressure versus time and the velocity versus distance gradients within the runner, minimizes clearance between the runner and runner housing, and maximizes the size of flow passages, all with minimal penalty on turbine efficiency. The flow characteristics of the new runner were analyzed using twodimensional and three-dimensional Computational Fluid Dynamic (CFD) models.

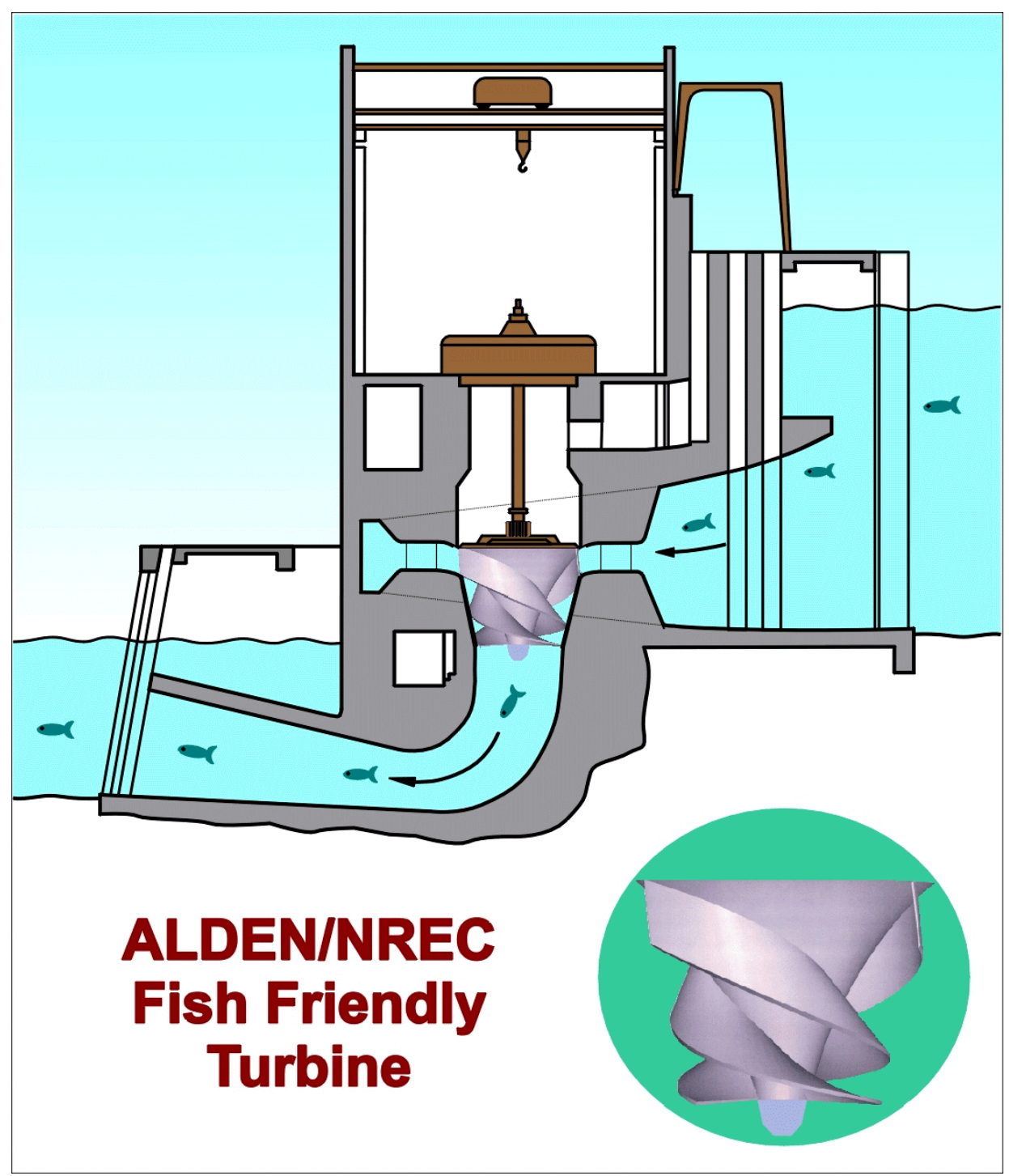

Figure 2. Conceptual design of the Alden/NREC runner developed under the U.S. Department of Energy's Advanced Hydropower Turbine Systems Program. 
The next step in development of this new design was to construct a prototype model and evaluate its biological performance and power output. In FY 2000, DOE supported additional studies of the new runner and the design of pilot-scale test facility that could be used in evaluating the performance characteristics of the new turbine.

This year's design work resulted in a proof-of-concept test facility proposal (Cook et al. 2000) that was reviewed and approved by the Technical Committee in March 2000. The test facility will center on an approximately 1/3-scale prototype runner that is large enough to pass fish. A 3.5-foot diameter runner will be installed in a closed, test flow loop with fish injection ports and a recovery screen (Figure 3). Construction on the ARL test facility began in late 2000. Full testing is expected to begin in Spring 2001. The upcoming test program will quantify the effects on fish passing through the runner and verify the basic hydraulic characteristics of the turbine runner.

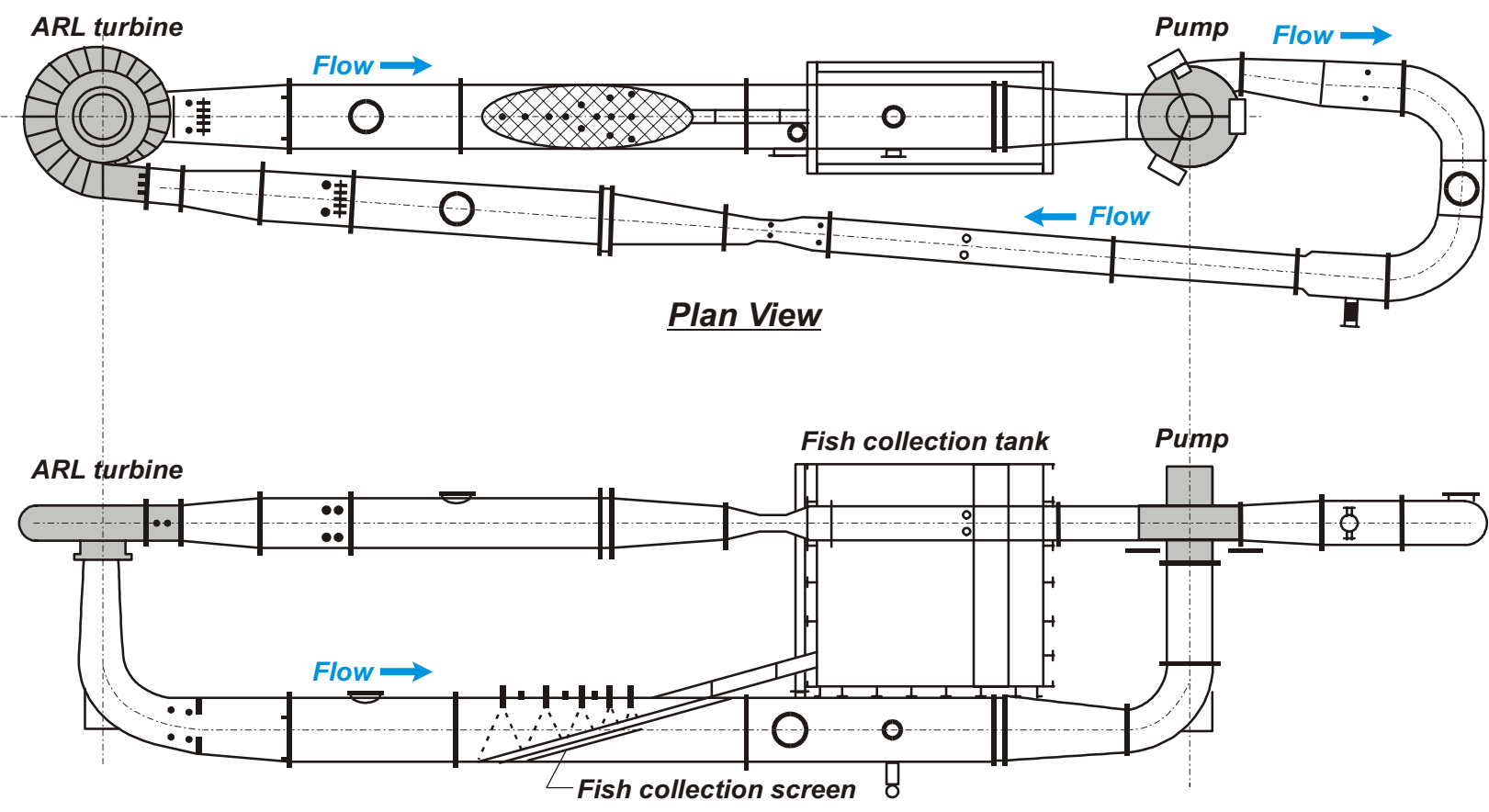

Cross-Sectional View

Figure 3. Configuration of the test loop and facility being constructed to evaluate fish survival in the new ARL/NREC runner. 


\section{MGR Testing at Bonneville Dam}

The Voith conceptual designs examined how existing turbine designs can be modified to improve efficiency and reduce environmental effects. Design concepts for improved fish passage survival in Kaplan and Francis turbines (as well as designs for boosting dissolved oxygen levels in discharges from Francis turbines) were developed. These concepts can be incorporated into rehabilitation or upgrading existing projects or into new installations.

Some of the fish-friendly features developed by the Voith team for the AHTS program have been incorporated into Voith's Minimum Gap Runner (MGR) turbines. The MGR design is a modification of a conventional Kaplan turbine, and has a number of features designed to reduce the mechanical damage to turbine-passed fish (Fisher et al. 2000). As the name implies, compared to a conventional Kaplan runner, the MGR reduces the gaps between the adjustable blade and the hub, and between the blade tip and the discharge ring (Figure 4). These modifications are expected to reduce the fish injury caused by pinching, cavitation, shear stress, and turbulence associated with the gaps found on conventional Kaplan runners (Figure 5). An MGR turbine was installed
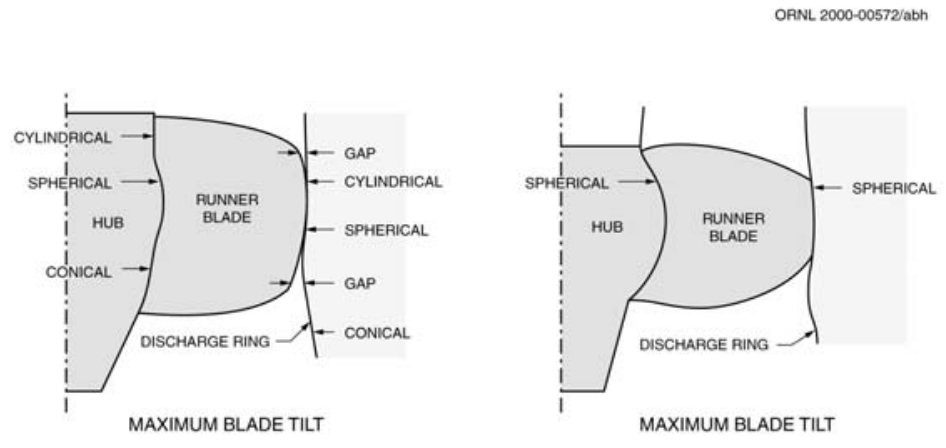

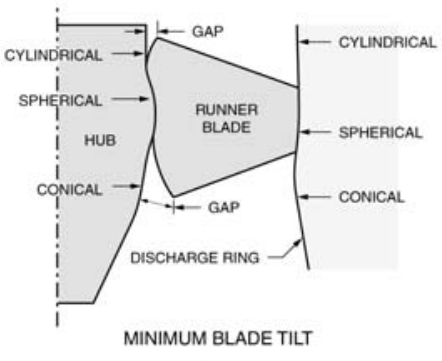

(a)

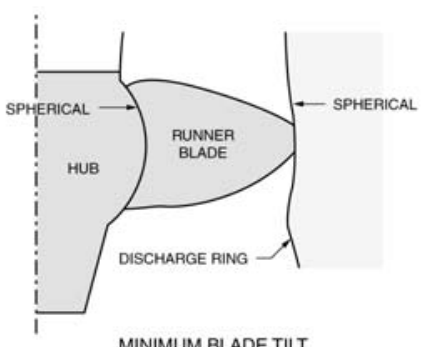

(b)

Figure 4. Comparison of: (a) conventional Kaplan turbine blades, and (b) the new Minimum Gap Runner (MGR) designs. 


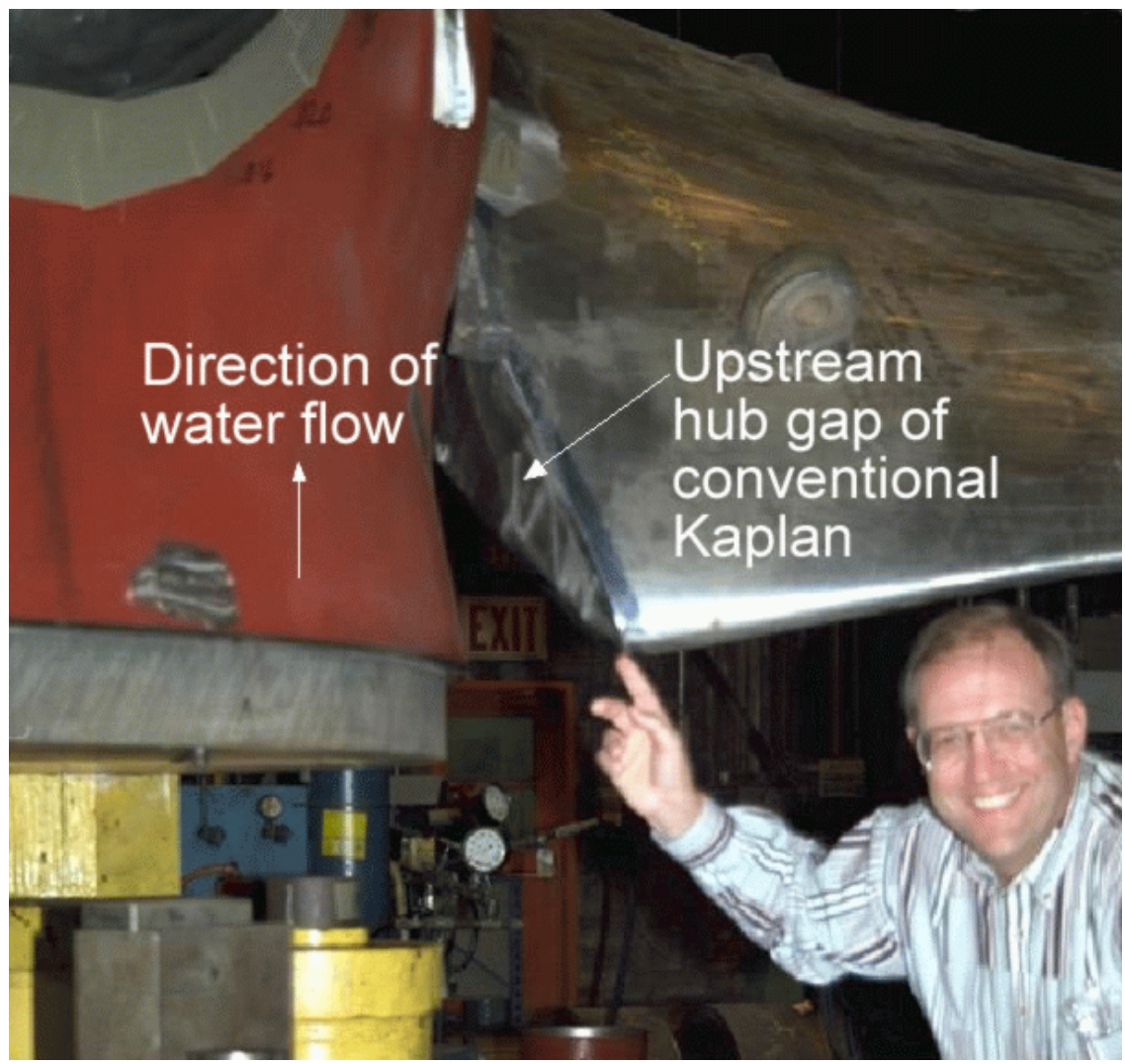

Figure 5. Example of the gaps between the blade and hub of Kaplan turbines which is thought to be the site of many fish injuries.

at the U.S. Army Corps of Engineers' (COE) Bonneville Dam on the Columbia River. The DOE Hydropower Program and others provided co-funding to the COE for fish passage survival tests in FY 2000.

The COE is in the process of installing MGRs on all ten units at the Bonneville I powerhouse (Chenoweth 1999). The first units to be replaced were Unit 6 (put into commercial operation on July 27,1999$)$ and Unit 4 (September 1999). The survival of turbine-passed fish is being studied to compare the performance of the new MGR in Unit 6 to that of an adjacent, conventional Kaplan turbine, Unit 5. The goal of the biological testing was to determine if the MGR is at least equivalent to the conventional turbine in terms of fish passage mortality (i.e., it will do no harm). The biological tests, funded by the COE, Grant County Public Utility District No. 2, U.S. Department of Energy, and the Bonneville Power Administration, were conducted between November 15, 1999 and January 31, 2000. Using 7,200 balloon-tagged fish, the study produced 24 survival estimates, one for each of the two turbines at four operating conditions with three release points. Considerable effort was devoted to releasing fish in areas that 
would cause them to pass near the hub, at the mid-blade region, and near the blade tip (Figure 6).

Preliminary analyses indicate that fish passed through the MGR had better survival overall than through the conventional Kaplan unit (Schwartz 2000). Overall injury rates among turbine-passed fish were low for both units $-1.5 \%$ and $2.5 \%$ for the MGR and Kaplan unit, respectively. Survivals of fish passed near the hub were high ( $97 \%$ or greater) for both units. Survivals among fish passed through the mid-blade region ranged from 95 to $97 \%$ and did not differ between units. At all four power levels, the MGR showed better survival than the conventional Kaplan for fish that passed near the blade tip. Survivals for blade tip-released fish ranged from 90.8 to $95.6 \%$ for the conventional Kaplan and from 93.8 to $97.5 \%$ for the MGR.

\section{BASIC AND APPLIED R\&D}

The DOE Hydropower Program supports a number of research projects that contribute to its goal of improving the environmental performance of hydropower technology. Most of these enable the development of advanced turbines by producing new understanding of the stresses that kill or injure fish. This has been challenging

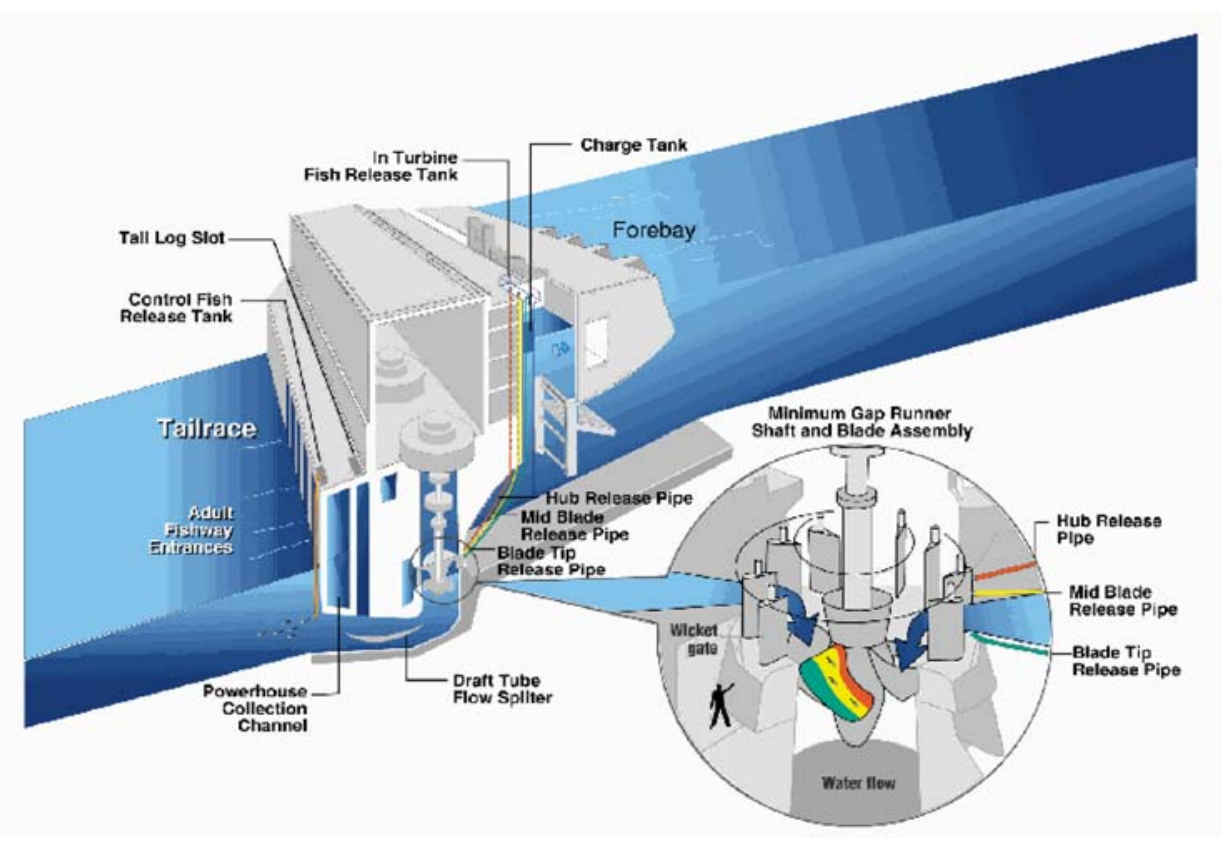

Figure 6. Testing the performance of a new MGR turbine at Bonneville Dam. 
because such potential injury mechanisms as rate of strain, turbulence, pressure changes, and the likelihood and severity of impact with structures are extremely difficult to measure inside of a turbine.

In FY 2000, three complementary efforts developed new understanding of effects on turbine-passed fish: (1) laboratory studies of the response of fish to turbinepassage stress mechanisms (using live fish); (2) field measurements of the physical conditions within portions of the turbine (using instrumented, sensor fish), and (3) application of advanced computational techniques to describe the hydraulic environment that fish experience (using virtual fish). All three components are needed to develop a better understanding of both the adverse effects of turbine-passage injury mechanisms and the modifications needed to reduce those effects (Čada et al. 2001). The integration of results from all three of these types of studies can improve the accuracy of predictive models and, in the future, may reduce the need for live fish in the testing of hydroelectric turbines.

\section{Laboratory Studies}

As conceptual designs for advanced turbines were being developed, it became clear that there were significant gaps in knowledge of fish responses to physical stresses experienced during turbine passage. Although the potential injury mechanisms affecting turbine-passed fish (Figure 7) were first described for the Hydropower Program in the 1990s (e.g., Čada 1990; Čada et al. 1997), many of these biological effects remain poorly understood (Čada 1998). Consequently, the Technical Committee recommended that the R\&D activities of the Program be broadened to include laboratory studies to develop biological criteria for turbines. In FY 2000, specific issues examined included effects of strain rate, pressure changes, and dissolved gas supersaturation.

Strain Rate Effects on Fish. The hydraulic forces (e.g., rate of strain, shear stress, and turbulence) experienced during passage through turbines, spillways, and fish bypass systems are some of the least-studied mechanisms that injure fish. A test facility where juvenile fish could be subjected to a range of shear environments was conceived through a joint effort of the National Laboratories and the AHTS Technical Committee and built at PNNL. Test fish (rainbow trout, steelhead, spring and fall chinook salmon, and American shad) were exposed to fluid stresses generated by a submerged jet (Figure 8) with a range of exit velocities from 0 to $21.3 \mathrm{~m} / \mathrm{s}(0$ to $70 \mathrm{ft} / \mathrm{s}$ ), resulting in a rate of strain of up to $1,185 \mathrm{~cm} / \mathrm{s} / \mathrm{cm}$ (based on a spatial resolution of 1.8 $\mathrm{cm}$ ). Fish were introduced to the edge of the submerged jet plume in either a headfirst or tailfirst orientation, recaptured, and observed for injuries and short- and long-term mortalities. 


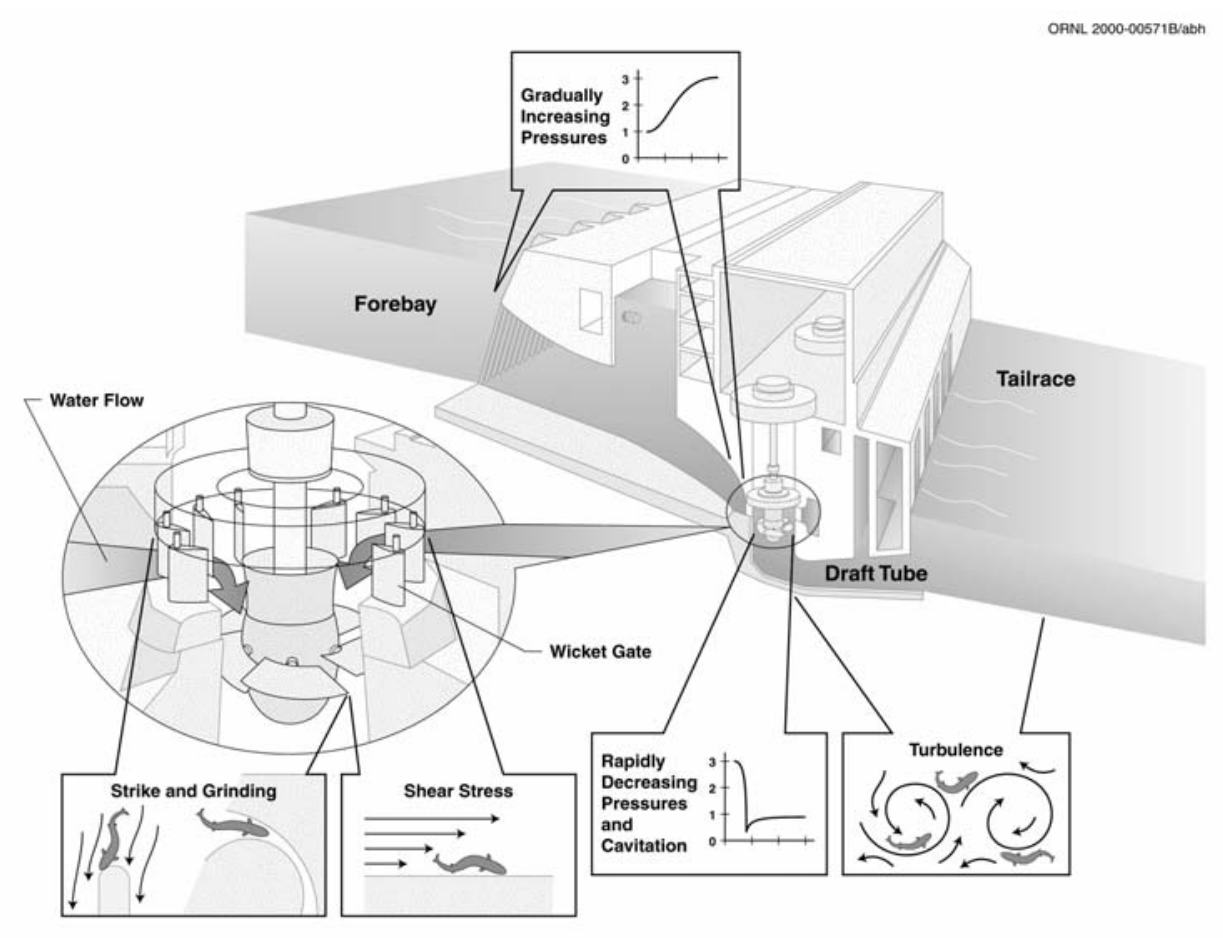

Figure 7. Physical injury mechanisms to fish passing through hydropower turbines.

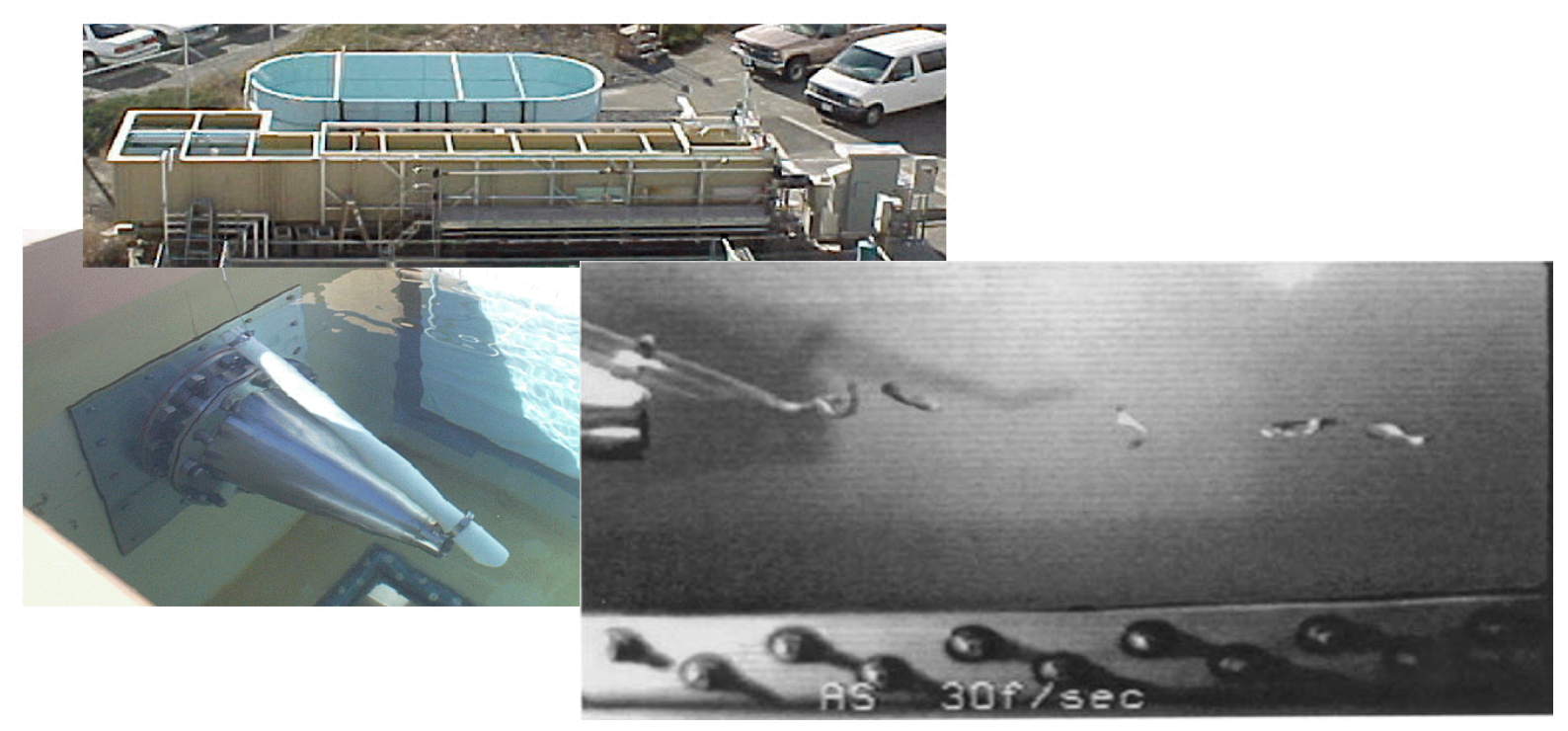

Figure 8. Photographs of the experimental test flume constructed at PNNL to study the effects of hydraulic shear on fish. 
Neitzel et al. $(2000 a, b)$ found that fish entering an environment with a high rate of strain may be killed, injured, or, if uninjured, still have increased susceptibility to predation. There were no significant injuries to any fish subjected to strain rates of less than $517 \mathrm{~cm} / \mathrm{s} / \mathrm{cm}$. Of the species tested, American shad were the most susceptible to injury, while steelhead and rainbow trout were least susceptible. Predation tests were conducted on rainbow trout; whereas strain rates of $688 \mathrm{~cm} / \mathrm{s} / \mathrm{cm}$ had caused no apparent injury, the test fish exposed to even lower values $(517 \mathrm{~cm} / \mathrm{s} / \mathrm{cm})$ were more susceptible to predation than control fish.

Pressure and gas supersaturation effects on fish. Studies of the effects of pressure changes during turbine passage have also been initiated at PNNL (Čada 1999), using a hyperbaric pressure chamber (Figure 9, top). In these experiments, test fish (juvenile rainbow trout, fall chinook salmon, and bluegill sunfish) were exposed to a pressure regime typical of passage through a Kaplan turbine, i.e., a gradual pressure increase to 3 times atmospheric pressure, followed by a rapid ( 0.1 second) decrease to sub-atmospheric pressure, followed by a gradual return to 1 atmosphere (Figure 9, bottom). When acclimated to surface water pressure, neither rainbow trout nor chinook salmon were killed by exposure to these turbine-passage pressures, although some injuries were observed (Abernethy et al. 2001). Bluegill exposed to the turbine-passage pressure regime had more injuries and mortalities than salmonids, especially if they had first been acclimated to water pressures equivalent to residence at 30 feet of depth. Gas supersaturated water, as commonly occurs in the Columbia River system, had adverse effects both separately and by increasing the injury and mortality due to turbine passage pressure changes.

Laboratory studies of turbine-passage injury mechanisms are continuing. The data will be used to develop biocriteria (biologically based design specifications) for the turbine manufacturers. When integrated with other components of the Program, the studies will give meaning to in situ measurements (from the field tests) and projected future conditions (from computational analyses).

\section{Field Studies}

Field studies supported by the Hydropower Program include measuring the success of new turbine installations to pass fish without excess mortality (e.g., MGR turbines at Bonneville Dam) and developing new technology to measure the physical stresses inside real turbines.

Sensor Fish. Many of the physical stresses that fish experience during turbine passage are difficult to measure with conventional instruments because localized regions deep within the turbine are inaccessible. DOE has supported, in part, the development of the sensor fish, a fish-shaped, smolt-sized package of instruments that, 


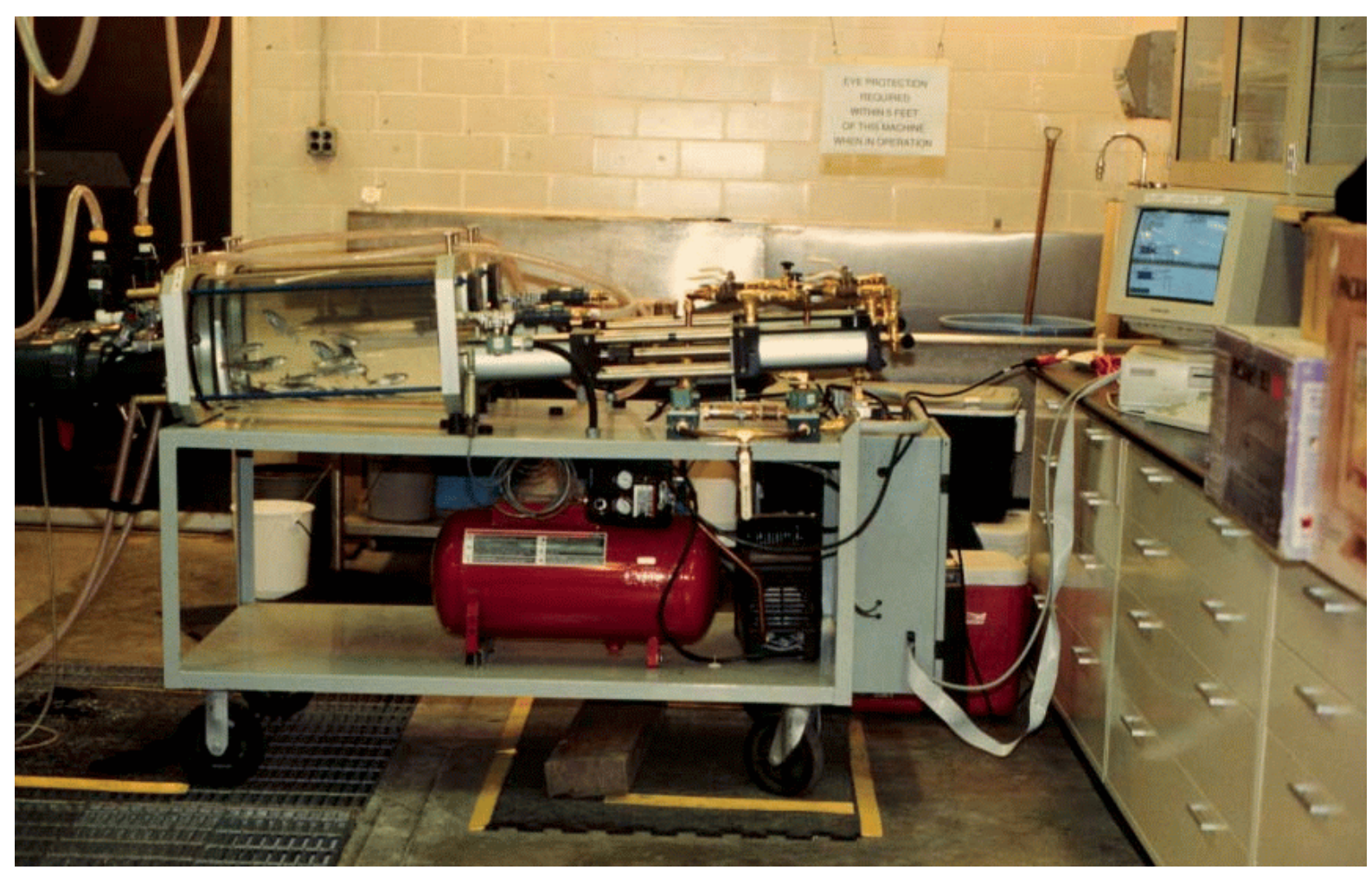

Figure 9. Photograph of experimental pressure chamber and pressure regime it reproduced to simulate conditions experienced by fish inside hydropower turbines.

like a real fish, can be sent through a turbine and recovered downstream. The sensor fish is an autonomous device containing pressure and acceleration sensors used to characterize conditions in severe hydraulic environments. The sensor housing is constructed of clear polycarbonate plastic and is $7.5 \mathrm{in}$. long and 2 in. in diameter. The sensor contains two types of transducers, a pressure transducer and 3 accelerometers in a tri-axial configuration. The remainder of the sensor electronics consists mainly of batteries, a power supply, analog to digital converter, memory, and communication components.

Before deployment in the test environment, specially designed balloons containing a gas-producing chemical are attached to the sensor fish, along with a micro-radio transmitter. Immediately before being placed in the induction system, the sensor data acquisition sequence is initiated and the balloons are injected with hot water. Balloon inflation is delayed by the time required for the capsule containing the gas-producing chemical to dissolve, which can be adjusted by the temperature and amount of water injected. The balloons generally inflate within a few minutes of release and bring the sensor fish to the surface of the tailrace, where a crew in a boat recovers it. Upon recovery, the sensor is connected to a computer and the data acquired in 
memory are downloaded. Following data recovery, the sensor's memory is erased and batteries are recharged.

Data acquired using the sensor fish are being used to determine the range over which hydro-turbines may be operated without severe impacts on fish passing through the turbines. It is also being used to provide data to identify improvement in turbine designs and various operational parameters to provide overall safer passage for fish.

\section{Computational Studies}

The Program's biological testing studies are generating valuable information on the effects of particular injury mechanisms associated with turbine passage that can be used to develop biocriteria for the design of advanced turbines. For example, if it is found that pressure effects are less damaging to salmon than fluid effects (strain rates and turbulence), the turbine manufacturer has a better basis for making design tradeoffs to protect fish. However, an additional consideration in applying these fish injury and mortality data is the spatial distribution and magnitude of stress mechanisms inside operating turbines. Although a given value for rate of strain may be damaging, it is of little consequence if such values only occur in a small portion of the turbine water passage, such that few turbine-passed fish are likely to encounter these values. The Program is supporting work in advanced computational analyses, such as computational fluid dynamics (CFD) modeling, to translate the laboratory data to the actual and projected turbine environments.

In FY 2000, two computational studies were supported. Investigators at the Georgia Institute of Technology and at Voith Siemens Hydro are conducting new CFD simulations of experimental tests in turbulent jet flows and existing turbines. This research is designed to better understand nature, magnitude, and location of the physical stresses that fish experience as they pass through hydroelectric turbines, to refine the previous CFD analyses of existing turbines, and to derive new design guidance for advanced turbines. These CFD studies complement the other lab and field studies.

Steady-State Simulation of Laboratory and Field Conditions. The objective Voith's work is to use traditional, steady-state CFD software to relate velocity field conditions and associated strain rate levels inside existing turbines with the biological response information derived from the PNNL test flume. Voith is using CFX-TASCflow software (AES TES 2000), a 3-dimensional viscous computer code, to simulate both the PNNL test flume and a Kaplan turbine at the Wanapum Dam on the Columbia River in Washington. Reynolds-Averaged Navier-Stokes equations with a standard k- $\varepsilon$ turbulence model were used for the calculations. Post-processing to calculate a rate of strain parameter comparable to the PNNL results is being done with Ensight software (CEI 2000). From this CFD modeling, an inventory is being made of the location and 
volume of damaging strain rate zones within the turbine. Specific travel paths through the fluid can also be classified in terms of shear stress to fish.

This work demonstrates how the combination of CFD and a series of design criteria is a valuable tool to evaluate turbine designs and find ways to reduce fish mortality. More extensive calculations of the turbine at additional operating points could shed light into the effects of operation on the volumes with particular rate of strain values, and provide more insight into development of Kaplan turbines that are more fish friendly than the current generation of designs. Voith's steady-state work will be coordinated with the parallel, unsteady-state research at Georgia Tech. This will allow comparisons of velocity fields and predictions of strain rate levels that are based on different CFD methods, thereby providing better understanding of the value of alternative modeling approaches.

Unsteady-State Simulations. A numerical method for carrying out large-eddy simulations (LES) of turbulent free shear flows is being developed at Georgia Tech. This unsteady-state model is then being used to simulate the velocity fields and shear levels in the PNNL test flume and to compare the predictions of steady (i.e., timeaveraged) models with unsteady models. The objective of the unsteady modeling is to clarify the complex features of the instantaneous flow field to help interpret the results of the biological experiments. The patterns of critical thresholds of strain rate and turbulence-induced loads are very different in the steady and unsteady modeling results. Comparisons between observed and simulated data reveal that the simulated mean flow axial velocity profiles are in good overall agreement with the measurements. The calculated instantaneous flow fields are analyzed in detail and their complex, highly three-dimensional, and unsteady structure is juxtaposed with the relative simple structure of the time-averaged flows. Particle tracking studies are also being carried out to analyze the computed flow fields from the so-called Lagrangian viewpoint, that is, from the viewpoint of a fish transported by and interacting with the turbulent flow. The results demonstrate that the actual flow environment experienced by the fish is vastly more complicated than that described by the mean flow. There is a need for understanding and quantifying the structure of turbulence at the size scale of a fish to guide the design and interpret the results of laboratory experiments with live fish.

Additional software, the Virtual Fish (VF) model (another product from earlier stages of the AHTS program), is being used with the steady flow simulations to estimate flow-induced loads on test organisms. The VF model encompasses a set of algorithms and numerical techniques that allow the prediction of fish trajectories through a power plant by the numerical solution of the equations of motion of a statistically adequate number of fish. The estimates of flow-induced loads on the VF will be compared to the response of live organisms in the PNNL test flume. 


\section{Synthesis and Integration}

Measurements of the locations and magnitudes of suspected fish injury mechanisms within a turbine can only come from field studies at hydroelectric power plants. These measurements are done with conventional instruments where possible, but a more intensive look at the complex hydraulic conditions within a turbine often requires the development of advanced measuring techniques such as the sensor fish. Then, the significance of these measurements to fish injury and mortality must be established under controlled conditions in the laboratory. Laboratory studies will determine whether some injury mechanisms are more harmful than others, information that will be used by the turbine manufacturer to make design tradeoffs. Advanced computational analyses serve a variety of purposes, including estimating conditions within unmeasured areas of the turbine, elucidating the causes for observed fish injuries in the laboratory, and predicting the effects of turbine design changes on fish survival. Coming full circle, field studies of turbine passage survival are again needed to verify the projected biological benefits of changes in turbine design and operation that were suggested by the earlier studies. By systematically exploring the turbinepassage issue and integrating the findings of different approaches, turbine manufacturers will be able to move beyond a trial-and-error approach to advanced turbine development.

\section{ENVIRONMENTAL MITIGATION AND OTHER STUDIES}

The environmental issues associated with hydropower go well beyond hardware design, so the Hydropower Program includes a diverse array of other studies supporting program goals. In FY 2000, funding to support these other studies was limited. Nevertheless, several important activities continued in this area.

\section{Dissolved Oxygen Management Approaches}

Low dissolved oxygen (DO) concentrations pose a common water quality problem downstream of hydropower facilities. In recent years, engineering improvements (e.g., installation of weir dams or aerating turbines) have dramatically improved water quality at some facilities. However, even with these improvements, many hydropower projects are unable to meet state water quality standards for DO. With numerous dams across the nation coming up for relicensing and recent regulatory changes to more watershed-based approaches (like the Total Maximum Daily Load [TMDL] program), it is increasingly important that the hydropower industry understand its options for addressing DO issues. In addition to engineering controls (structural measures), hydropower facilities may consider operational changes and watershed management techniques (Peterson et al. 2001). To address these issues, the DOE Hydropower Program is supporting a new mitigation report on the major non-structural approaches for addressing the DO problems at hydropower facilities. 
Operational changes to raise downstream DO concentrations include: (1) fluctuating the timing and duration of flow releases, (2) spilling or sluicing water, 3) maintaining minimum flows, and 4) mixing of generation and auxiliary flows. An advantage of watershed management approaches to regulating water quality is that hydropower impacts (both positive and negative) could be considered together with other point and nonpoint discharges at the watershed scale. For example, in the case of watershed-based pollutant trading, it is conceivable that an upstream industry could pay for DO improvements at the downstream dam in lieu of more expensive in-plant source reductions. A watershed management approach may also substitute biological or ecological criteria for strict DO standards for meeting water quality goals, or conduct riparian or aquatic habitat improvements. Depending on the site-specific situation and the relative cost-benefits, hydropower facilities may need to use a combination of structural, operational, and watershed management approaches to adequately address the DO issue. A report on these DO mitigation issues will be available in 2001 .

\section{Hydropower Impacts on American Eel}

Worldwide, stocks of catadromous anguillid eels are in apparent decline. The reasons for the decline are unknown, but may include oceanic influences, pollution, over-fishing, predation, disease, and direct (turbine mortality) and indirect (changes in habitat availability) impacts caused by hydroelectric and other water resource development projects. To understand the role that hydroelectric facilities may be playing in this decline, DOE is providing partial funding to an EPRI study of eels. The EPRI study is focusing on existing technologies and on-going research related to minimizing turbine entrainment of downstream migrating eels, directing them to downstream passage facilities, and successfully passing eels around hydroelectric projects. The individual component stresses that contribute to turbine-passage mortality will be described along with available mitigation options. Because protection and passage of catadromous eels is an international issue, the objective of the study is to identify and review current and developing methods throughout the United States, Canada, Europe, New Zealand, Australia, and Asia. Ultimately, a more comprehensive EPRI report will be produced, including complete descriptions of the design, installation, effectiveness, and positive and negative aspects of each mitigation technology investigated.

\section{Hydropower Certification Programs}

The restructured electricity market is creating new opportunities and new pressures on hydropower. The Program is tracking these trends, with special attention to the development of new green energy certification programs and their impact. The Low Impact Hydropower Institute is preparing a report for DOE on its first-year experiences in certifying hydropower projects. This report that will summarize the early experiences in the green energy certification arena, including recommendations on how DOE-sponsored R\&D can help make projects more acceptable. ORNL is also providing technical support to this activity. Understanding this evolutionary process will 
complement the activities in DOE's Hydropower Program and help to define future research needs.

\section{Streamside Incubation Project}

The U.S. Department of Energy and the U.S. Department of Navy are cosponsoring Indian Summer research experiences for students of the Shoshone-Bannock tribe in Idaho. The projects involved placing 1 million steelhead eggs per year in special incubators in streams and tributaries of the Salmon river. The objective was to increase the hatch rate of the eggs and survival rate of the smolts (Galindo and Rinehart 1998).

\section{LOW HEAD/LOW POWER HYDROPOWER TECHNOLOGY}

While the bulk of current Program activities are aimed at conventional hydropower plants that use conventional turbines and sites, there is also a need to develop what can be called unconventional turbine designs, such as free-flow turbines or designs for low-head (30 feet or less) sites that have a capacity of $1 \mathrm{MW}$ or less. Generally, low-head sites have fewer environmental problems, although individual sites may still have specific environmental issues. New turbine designs have been developed that may have low environmental impact, and some types of unconventional hydropower may be suitable for implementation as distributed power sources. The resources and potential market of this new technology needs to be further understood.

\section{Resource Assessment}

In FY 2000, DOE initiated planning for an assessment of potential resources appropriate for unconventional development. Three general classes of hydropower systems are being distinguished for the purposes of this task: (1) elevation-drop systems, (2) free-flowing rivers/streams, and (3) microhydro. An elevation-drop hydropower system is defined as any arrangement that uses a dam or natural drops. Free-flowing systems use the kinetic energy from the water in motion. Therefore, systems with a capacity from $1 \mathrm{MW}$ down to $100 \mathrm{~kW}$ will be evaluated as one case and microhydro systems with a capacity of $100 \mathrm{~kW}$ or less, will be evaluated as a separate case. The elevation will not be restricted to $30 \mathrm{ft}$ of hydraulic head for the case of 100 $\mathrm{kW}$ or less but will be for the case from $1 \mathrm{MW}$ to $100 \mathrm{~kW}$.

Each of these flow-stream systems impose constraints on the types of technologies that can be used. Additionally, when other criteria are used, the number of resources available for development are reduced. The INEEL will identify the flow streams that have a potential for hydropower development in the area of low head or low-power systems. The study's conclusions will contain the number of sites for each case and an estimate of potential power for each site, which will allow for a summarized estimate of the total potential power. The data in each report will be organized both by 
state and region. Planned resource assessment activities may include additional factors such as the economics and impacts due to projected climate change.

\section{Biological Performance Testing of Small-scale Turbines}

To evaluate the environmental performance characteristics of the more unconventional technologies, DOE has solicited applications from qualified turbine developers to participate in cost-shared field testing. DOE would provide funding for studies of fish passage at sites with low-power ( $<1 \mathrm{MW})$ or low-head ( $<30 \mathrm{ft}$ head) turbines. Qualified applicants would have to own rights to the turbine technology tested, and the equipment would have to be fully designed and either existing or readily constructed. The response to this solicitation will not be known until early 2001.

\section{TECHNOLOGY TRANSFER}

An important component of DOE's Hydropower Program has always been the transfer of new information to the hydropower community. In general, this occurs through technical support to professional conferences, publications, ad hoc meetings to coordinate interagency research activities, and on-call assistance from DOE and Laboratory staff. Several specific examples of these activities are highlighted here from the past year.

\section{Recent Advances in Turbine Passage Technology}

To assist interagency cooperation and coordination, Čada and Rinehart (2000) assembled a report describing the ongoing and planned R\&D activities across the U.S. related to survival of fish entrained in hydroelectric turbines. This report identifies studies that are generating new information that can be used to mitigate turbinepassage mortality. The review summarized the effects on fish of physical or operational modifications to turbines, comparisons to survival in other downstream passage routes (e.g, bypass systems and spillways), and applications of new modeling, experimental, and technological approaches to develop a greater understanding of the stresses experienced by fish during passage through turbines. The concluding section provides answers to Frequently Asked Questions about turbine-passage survival.

\section{State of Science Report on Pacific Salmon Restoration}

Under the direction of the National Science and Technology Council's Committee on Environment and Natural Resources (CENT), an interagency partnership was formed in January 1999 to reverse dramatic declines in salmon occurring on the Pacific coast of the U.S. One of the elements in this partnership was to conduct a scientific assessment of risks to salmon throughout their life cycles and of the mitigation and recovery options available to reduce these risks. The DOE Hydropower Program provided technical assistance to this assessment through the efforts of staff at ORNL, 
who prepared initial drafts of a report on this subject. The final report, entitled From the Edge, Science to Support Restoration of Pacific Salmon, was published by CENT in November 2000 (CENT 2000). It points out that hydropower impacts are only one of the many factors affecting salmon, that much work has already been do to reduce hydropower's impacts, but also that additional research can lead to improvements in salmon survival at hydropower projects.

\section{Translation of Russian Research}

Russian scientists have been contributing to the understanding of hydropower effects for decades, but their findings are difficult to access because of language barriers. One example of an important Russian publication is a 1999 textbook entitled Fish Downstream Migration Through Dams of Hydroelectric Power Plants, by D.S. Pavlov, A.I. Lupandin, V.V. Kostin, of the A.N. Severtsov Research Institute of Ecology and Evolution, Russian Academy of Science Moscow-Nauka. The DOE Program is supporting the translation of this book from Russian to English. This book is a summary and synthesis of decades of Russian research into fish migration, and it describes how the regulated river flows affect fish downstream migration. The book is intended for ichthyologists, those who deal with the protection of the fish resources, as well as for hydroelectric and hydrotechnical engineers and fish industry experts.

\section{ANTICIPATED FUTURE ACTIVITIES}

The immediate plans for Advanced Hydropower Turbine System development are: to complete the biological and engineering testing of the ARL/NREC runner; to continue cooperative studies with the COE and its Turbine Survival Program; and to pursue new opportunities for cost-shared testing of the biological performance of new hydropower turbine technology. The primary focus of these activities will be to determine the fish passage characteristics of the turbine technology and to verify the environmental friendliness of the turbine. On a longer-term basis, the Program intends to support full-scale testing for new turbine concepts, subject to available funding.

DOE issued a solicitation in FY2000 to cost-share the testing of new turbine technology that is being developed outside the DOE program. Qualified participants with ownership rights to the turbine technology of less than $1 \mathrm{MW}$ capacity were invited to propose projects. Technology must also be advanced to the stage that hardware exists or can be readily constructed; i.e., the equipment design has been completed. Up to $\$ 2.5$ million for each of 2 years will be available to support at least one or more testing projects.

DOE also plans to issue a solicitation for cost-shared biological testing of new, larger-scale, hydropower turbines. The primary object of this project is to determine the fish passage characteristics of the turbine technology and to verify the environmental friendliness of the turbine. Qualified participants must own the rights to the turbine 
technology. The technology must also be advanced to the stage that hardware exists or can be readily constructed, i.e., design has been completed. This project is limited to turbines that have an electrical generating capacity greater than $1 \mathrm{MW}$.

With regard to basic and applied R\&D, the combined field, laboratory, and computational research described here will continue in future years. One specific direction of future studies will be in understanding the turbulent environment downstream of the turbine runners, in the draft tube and tailrace of hydropower plants. This work is likely to include both physical characterization of existing plants and additional biological studies to further define, enhance and test the biological criteria as the technology progresses. The work on advanced sensors will also continue, to develop better ways to track fish through turbine systems and to relate fish response to the cumulative stresses from hydropower systems. Another research need that will be addressed, as funding allows, is the development of new techniques to assess and better predict predation and other forms of indirect mortality.

Additional mitigation studies and other reports are planned in the future. At the North American Hydro Research and Development Forum conducted in 1992, the hydropower industry reviewed research efforts in the industry and identified research needs. A smaller industry-government R\&D summit was held in November 2000 to revisit research needs, and this planning effort will be repeated immediately after Waterpower XII at an R\&D Forum in Salt Lake City in July 2001. Many of the issues identified at these meetings continue to be assessed and remain targets for future research efforts.

As future budgets allow, additional studies will be added to the Program. One high priority is to restart the environmental mitigation studies to address unresolved issues such as instream flow requirements and methods to enhance passage of migratory fish through the reservoir system. These items have been identified by the hydropower industry as high-priority issues. Other issues that may be supported in the future include the development of industry guides to address the operating and maintenance of the power plant and resources and dam decommissioning.

Future activities in the area of unconventional hydropower technologies include assessing the potential application of new technologies in the U.S. and initiating the testing of new low-head/low-power turbine technology. The environmental performance of this technology must be tested to support commercial development. Studies are needed to identify new technologies with desirable fish passage characteristics that have been developed outside the current DOE program.

\section{CONCLUSIONS}

The DOE Hydropower Program continues to make unique contributions to clean energy production in the U.S. By working toward technology improvements that can 
reduce environmental problems, the Program is helping position hydropower as an acceptable, renewable, domestic energy choice. Hydropower Program activities are closely coordinated with industry, other federal agencies, and public interest groups to ensure an efficient, open, and scientifically sound research agenda. DOE funding is leveraged with cost-sharing whenever possible, and peer-review processes are used in making funding decisions.

For more information on the DOE Hydropower Program, contact:

Peggy Brookshier

U.S. Department of Energy

Idaho Operations Office

850 Energy Drive, MS 1220

Idaho Falls, ID 83401-1563

Tel: (208) 526-1403; Fax: (208) 526-5964; E-mail: brookspa@id.doe.gov

John V. Flynn

U.S. Department of Energy

Office of Biopower and Hydropower Technologies

EE-13 Room 5H/047

1000 Independence Avenue S.W.

Washington, DC 20585

Tel: (202) 586-8171; Fax: (202) 586-5879; E-mail: john.flynn@hq.doe.gov

Michael J. Sale

Oak Ridge National Laboratory

P.O. Box 2008

Oak Ridge, TN 37831-6036

Tel: (865) 574-7305; Fax: (865) 576-8543; E-mail: salemj@ornl.gov

Glenn F. Čada

Oak Ridge National Laboratory

P.O. Box 2008

Oak Ridge, TN 37821-6036

Tel: (865) 574-7320; Fax: (865) 576-3989; E-mail: cadagf@ornl.gov

Garold L. Sommers

Idaho National Engineering \&Environmental Laboratory

2525 Fremont Ave.

Idaho Falls, ID 83415-3830

Tel: (208) 526-1965; Fax: (208) 526-0969; E-mail: sommergl@inel.gov 
Dennis D. Dauble

Pacific Northwest National Laboratory

Battelle Boulevard

P.O. Box 999

Richland, WA 99352

Tel: (509) 376-3631; Fax: (509) 372-3515; E-mail: dd.dauble@pnl.gov

Ben Rinehart

2008 Olympia Drive

Idaho Falls, ID 83402-1623

Tel: (208) 522-4289; Fax: (208) 522-7413; E-mail: rinehabn@srv.net

\section{REFERENCES CITED}

AEA TES (AEA Technology Engineering Software, Ltd.), 2000, CFX-TASCflow Computational Fluid Dynamics Software Primer Documentation Version 2.10. 554 Parkside Drive, Waterloo, Ontario, Canada N2L 5Z4, 2000.

Brookshier, P. A., J. V. Flynn, and R. R. Loose, 1995, " $21^{\text {st }}$ Century Advanced Hydropower Turbine System," Proceeding of Waterpower '95, American Society of Civil Engineers, New York, New York, pp. 2003-2008.

Brookshier, P.A. and J.V. Flynn, 2001, "What's Up DOE?" Proceedings of the Waterpower XII Conference, $\mathrm{HCl}$ Publications, Inc., Kansas City, MO.

Čada, G. F., 1990, "A Review of Studies Relating to the Effects of Propeller-Type Turbine Passage on Fish Early Life Stages," North American Journal of Fisheries Management 10(4):418-426.

Čada, G. F., C. C. Coutant, and R. R. Whitney, 1997, Development of Biological Criteria for the Design of Advanced Hydropower Turbines. DOE/ID-10578. U.S. Department of Energy Idaho Operations Office, Idaho Falls, Idaho.

Čada, G. F., 1998, "Better Science Supports Fish-Friendly Turbine Designs," Hydro Review XVII (6):52-61.

Čada, G. F., 1999, Effects on Fish of Changes in Water Pressure and Dissolved Gas Saturation Associated with Hydroelectric Turbine Passage - Considerations for Biological Tests. Report prepared for the U.S. Department of Energy Idaho Operations Office, Idaho Falls, Idaho.

Čada, G. F., and B. N. Rinehart, 2000, Recent R\&D Advances in Turbine Passage Technology. DOE/ID-10753. U.S. Department of Energy Idaho Operations Office, Idaho Falls, Idaho. 
Čada, G.F., G.L. Sommers, and M.J. Sale, 2001, "What's Going On in There? Efforts to Describe the Experiences of Turbine-Passed Fish," Proceedings of Waterpower XII, $\mathrm{HCl}$ Publications, Inc. Kansas City, Missouri.

CEI (Computational Engineering International, Inc.), 2000, Ensight User Manual for Version 7.1, P.O. Box 14306, Research Triangle Park, NC 27709, April 2000.

CENT (Committee on Environment and Natural Resources), 2000, From the Edge, Science to Support Restoration of Pacific Salmon. National Science and Technology Council, Office of Science and Technology Policy, Washington, DC. November 2000. (Copies available through the Office of Policy and Strategic Planning, National Oceanic and Atmospheric Administration and at: www.nnic.noaa.gov/CENR/cenr.html).

Conner, A.M., J.E. Francfort, and B.N. Rinehart, 1998, U.S. Hydropower Resource Assessment Final Report. DOE/ID-10430.2, for the U.S. Department of Energy Idaho Operations Office, Idaho Falls, Idaho.

Cook, T. C., G. E. Hecker, H. B. Faulkner, and W. Jansen, 1997, Development of a More Fish Tolerant Turbine Runner. ARL Report No. 13-97/M63F, for the U.S. Department of Energy Idaho Operations Office. Alden Research Laboratory, Inc., Holden, Massachusetts.

Cook, T. C., S.A. Cain, P. Fetfatsidis, G.E. Hecker, and P.S. Stacy, 2000, Final Turbine and Test Facility Design. Final report to the Idaho Operations Office, U.S. Department of Energy. Alden Research Laboratory, Inc. and Northern Research and Engineering Corporation, Holden, Massachusetts. August 2000.

Coutant, C. C., and R. R. Whitney, 2000, "Fish Behavior in Relation to Passage Through Hydropower Turbines: A Review," Transactions of the American Fisheries Society 129:351-380.

Fisher, R., D. Mathur, P. G. Heisey, R. Wittinger, R. Peters, B. Rinehart, S. Brown, and J. R. Skalski, 2000, "Initial Test Results of the New Kaplan Minimum Gap Runner Design on Improving Turbine Fish Passage Survival for the Bonneville First Powerhouse Rehabilitation Project," Proceedings of the $20^{\text {th }}$ IAHR Symposium on Hydraulic Machinery and Systems, International Association of Hydraulic Research, Charlotte, NC, Aug. 6-9, 2000.

Francfort, J. E., G. F. Čada, D. D. Dauble, R. T. Hunt, D. W. Jones, B. N. Rinehart, G. L Sommers, and R. J. Costello, 1994, Environmental Mitigation at Hydroelectric Projects, Vol. II. Benefits and Costs of Fish Passage and Protection. DOE/ID-10360(V2). U. S. Department of Energy Idaho Operations Office, Idaho Falls, Idaho.

Franke, G. F., D. R. Webb, R. K. Fisher, D. Mathur, P. N. Hopping, P. A. March, M. R. Headrick, I. T. Laczo, Y. Ventikos, and F. Sotiropoulos, 1997, Development of 
Environmentally Advanced Hydropower Turbine System Concepts. Report No. 26770141. Voith Hydro Inc., prepared for the U.S. Department of Energy Idaho Operations Office, Idaho Falls, Idaho.

Galindo, E. and B. Rinehart, 1998, Indian Summer IV, Student Streamside Egg Incubation Project. Sho-Ban School, Fort Hall, Idaho.

$\mathrm{HCl}(\mathrm{HCl}$ Publications, Inc.), 1992, Repowering Hydro Through Research and Development: Viewpoints of the U.S. Hydroelectric Industry. Report to the U.S. Department of Energy. HCI Publications, Inc., Kansas City, Missouri.

Mattice, J. S., 1991, "Ecological Effects of Hydropower Facilities," Chapter 8 In J. S. Gulliver and R.E. A. Arndt (eds.), Hydropower Engineering Handbook, McGraw-Hill, Inc., New York, New York.

Neitzel, D.A., D. Dauble, M. Richmond, and G. Čada, 2000a, "Developing Biological Specifications for Fish Friendly Turbines," Proceedings of HydroVision '00, $\mathrm{HCl}$ Publications, Kansas City, MO.

Neitzel, D.A., M.C. Richmond, D.D. Dauble, R.P. Mueller, R.A. Moursund, C.S. Abernethy, G.R. Guensch, and G.F. Čada, 2000b, Laboratory Studies on the Effects of Shear on Fish: Final Report. DOE/ID-10822, U.S. Department of Energy Idaho Operations Office, Idaho Falls, Idaho.

Odeh, M., 1999, A Summary of Environmentally Friendly Turbine Design Concepts. DOE/ID/13741, U.S. Department of Energy, Idaho Operations Office, Idaho Falls, Idaho.

Peterson, M.J., G.F. Čada, and M.J. Sale, 2001, "Non-Structural Approaches for Addressing Dissolved Oxygen Concerns at Hydropower Facilities," Proceedings of Waterpower XII, HCl Publications, Inc. Kansas City, Missouri.

Sale, M. J., G. F. Čada, L. H. Chang, S. W. Christensen, J. E. Francfort, B. N. Rinehart, S. F. Railsback, and G. L. Sommers, 1991, Environmental Mitigation at Hydroelectric Projects. Vol. I. Current Practices for Instream Flow Needs, Dissolved Oxygen, and Fish Passage. DOE/ID-10360, U.S. Department of Energy, Idaho Falls, Idaho.

Sale, M.J., G.F. Čada, B.N. Rinehart, G.L. Sommers, P.A. Brookshier, and J.V. Flynn, 2000, "Status of the U.S. Department of Energy's Advanced Hydropower Turbine Systems Program," Proceedings of the $20^{\text {th }}$ IAHR Symposium on Hydraulic Machinery and Systems, International Association of Hydraulic Research, Charlotte, NC, Aug. 6-9, 2000.

Schwartz, D., 2000, "CRMFP - System Study Turbine Survival Program," Proceedings of the Turbine Passage Survival Workshop, T. Carlson (editor). June 14-15, 2000, U.S. Army Corps of Engineers, Portland District, Portland, OR. 
